Document downloaded from:

http://hdl.handle.net/10251/131618

This paper must be cited as:

Montaner-Marco, J.; Carrión-Plaza, A.; García Sanjuan, F.; Jaén Martínez, FJ. (2019). Tangibot: A collaborative multiplayer game for pediatric patients. International Journal of Medical Informatics. 132. https://doi.org/10.1016/j.ijmedinf.2019.103982

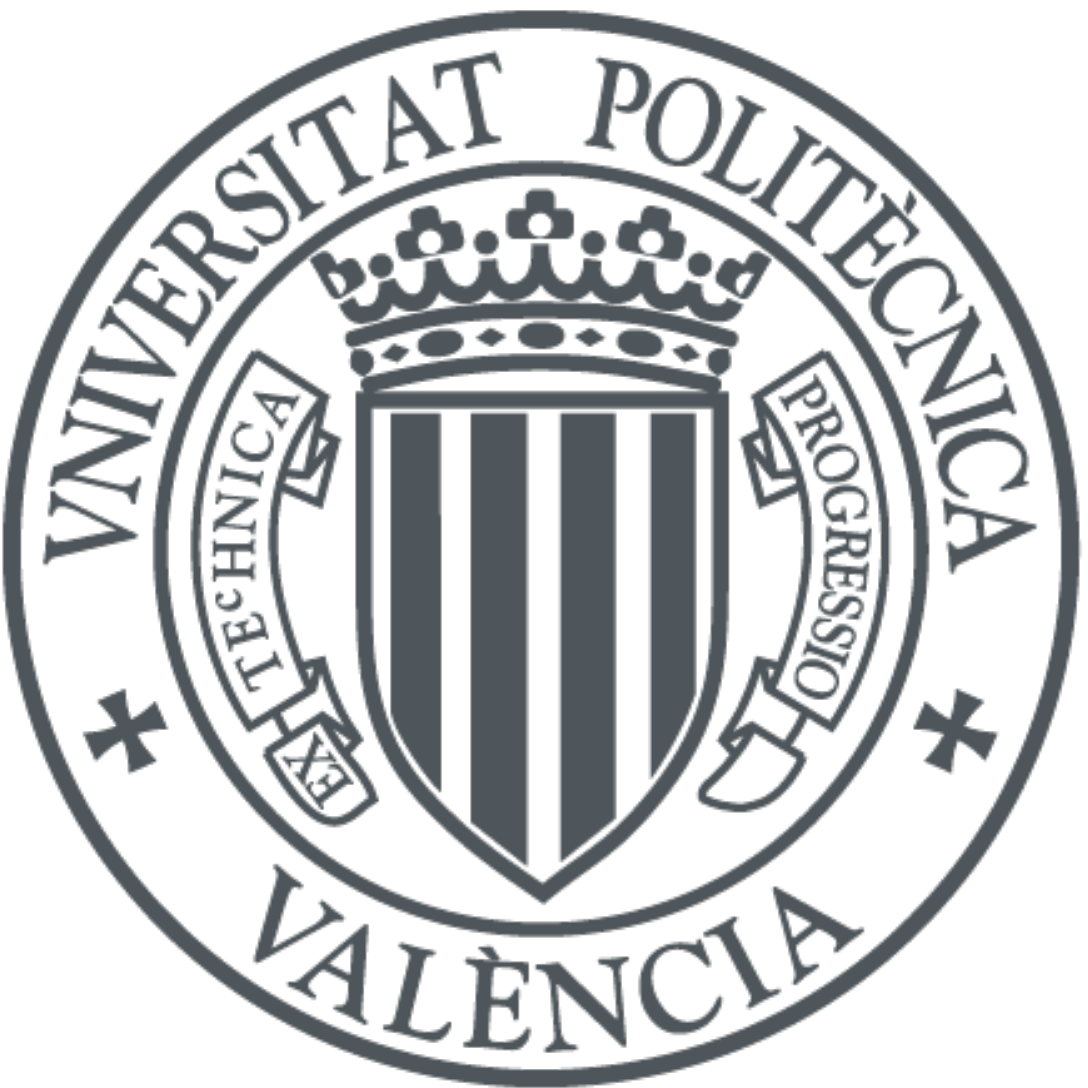

The final publication is available at

https://doi.org/10.1016/j.jimedinf.2019.103982

Copyright Elsevier

Additional Information 


\section{Tangibot: a collaborative multiplayer game for pediatric patients}

Authors: Jorge Montaner a*, Alicia Carrión ${ }^{b}$, Fernando García-Sanjuán ${ }^{a}$, Javier Jaén ${ }^{a}$

Email addresses: jormonm5@dsic.upv.es (Jorge Montaner), alicia.carrion@uv.es (Alicia

Carrión), fegarcia@dsic.upv.es (Fernando García-Sanjuán), fjaen@upv.es (Javier Jaén)

a ISSI research group, Departamento de Sistemas Informáticos y Computación (DSIC),

Universitat Politècnica de València, Camino de Vera s/n, 46022, València, Spain

${ }^{b}$ Departamento de Personalidad, Evaluación y Tratamientos Psicológicos, Psychology Faculty, Universitat de València, Avenue Blasco Ibáñez 21, 46022, València, Spain

* Corresponding author. Tel.: +34 963877000 ext. 83525

Keywords

Pediatric socialization, children hospitalization, gamification, socialization 


\section{Abstract}

\section{Background}

Previous research has studied the effects of games in pediatric wards, but none of it has focused on the impact of the hospital's school staff on the psychosocial state of the children nor on the gameplay itself.

\section{Objectives}

To present the Tangibot application and evaluate its impact on the children's psychosocial state in the short term and the impact of the teacher on their psychosocial state, communications and coordination during the activity.

\section{Methods}

A study was conducted in a hospital classroom with 20 participants, who participated twice in the game: one with the teacher playing along and another without her. An observational scale was used by two evaluators in order to assess the impact on the children.

\section{Results and conclusions}

The study revealed that the teacher has an impact on the children's communication and coordination procedures but has no impact on the psychosocial state of the participants. The teacher's impact was found to be positive about communications. Dialogue management significantly improves when the communication includes the teacher, which means speaking turns are observed more consistently. Information pooling also improves, and the participants ask the teacher more questions. Consensus is also reached more often and more easily, but this does not reflect on the performance, as the time management is evidently worse when the teacher is present, as is also the joint task orientation.

On the other hand, it was found that the teacher does not have an impact on the psychosocial state of the participants during the game, and that it is the game itself which changes their 
state over time. In the case of affection, which reflects the participants' emotions of joy or boredom, their state improved significantly after a few minutes of play. The same thing occurred for physical activity, interest in the activity and interaction between peers, which increased in value in the first part of the game, although physical activity and interaction were reduced towards the end. No changes were found throughout the game in the number of complaints, nervousness or satisfied comments, which remained very low for all these aspects, showing that the game distracted them from their various symptoms.

Based on these results, future work will explore the effects of gamification on the overall hospitalization perception, with special focus on the social opportunities during the hospital stay, to provide ways for the children to meet others during their treatment, to make the experience less painful and reduce their feelings of isolation. Some game strategies should also be evaluated to determine the ones that provide the best opportunities to improve the children's hospital experience.

\section{Introduction}

\subsection{Motivation}

Hospitalization is often a difficult experience for pediatric patients because it involves many elements which cause anxiety and fear, for example being in a strange environment, separated from their families, painful medical procedures or uncertainty about the future [1], [2]. These psychological consequences are not limited to the period of treatment inside the hospital, but can continue afterwards [3]. Among the problems they have to deal with is not being able to communicate with other children [4].

In this respect, hospitals do not usually offer the necessary tools for children to have a positive social experience, which could be helpful to them for their recovery and peace of mind [5]. In fact, these patients require hospital designs in which there are more possibilities of social 
interactions with other patients and with people outside the hospital. They would also like to have more technology available to them as a play and distraction mechanism [6].

Children can develop their social skills with games and activities [7]. Some games can promote collaboration between peers in order to reach a common goal, which in turn promotes their interaction and provides opportunities to socialize [8].

However, although Computer Supported Collaborative Play (CSCP) techniques have been evaluated in schools [9], few studies have analyzed how these strategies can be implemented in a children's ward or how they could benefit socialization possibilities and the children's general wellbeing. This paper describes a study on how CSCP can be applied in a pediatric context by implementing a prototype collaborative game and analyses its impact on children's communication strategies. It also examines the role of teachers in hospital context during CSCP and discusses the design guidelines that should be applied in future CSCP developments for hospitalized children.

\section{Related work}

There are examples of studies in the literature on the use of gamification to encourage socialization and collaboration in children. For instance, the works of [10] and [11], who used gamification in a collaborative-learning environment focused on Computer Science students, through the introduction of points, levels or ranks, which was positively accepted by the participants. Another study on the same lines is [9], which found that a multi-tablet game to enhance collaborative learning in Primary Education obtained positive collaboration and socialization results from the participants.

However, in all these examples the participants involved were not in an emotionally-stressful situation, which could hinder socialization. Also, the children already knew their classmates, so that they had already developed natural social interactions. These conditions are very different 
to those in pediatric environments, where children may be isolated and have fewer opportunities to socialize with peers, all of which means that it is not possible to extrapolate the results obtained to the pediatric context.

The use of CSCP in pediatric environments has been previously analyzed in a systematic review [12] that found two main approaches, co-located (i.e. children play in a common physical space) versus remote collaborative play.

Although these studies show that there is a demand for social games and that positive results were obtained in terms user acceptance and psychological effects, they do not consider the possible impact of adults or tutors on the gaming experience, lack the benefits of face-to-face communication for socialization and do not study how the game design affects the way in which communication takes place. This impact could be of relevance, as there is evidence on the importance of adults in the social and cognitive development of children and their socialization with peers [13] [14].

Our approach aims to enhance collaboration and socialization among hospitalized children through educational activities, as in [10] [11] or [9], but inside the hospital, with a co-located CSCP approach. We also consider the role of the teacher or tutor in the game and in the way collaboration and communication takes place. Our work is a first step towards understanding the design factors of co-located CSCP approaches that should be considered to foster socialization in pediatric contexts.

\section{Tangibot: a multi-tablet Gamified quiz system}

Tangibot was designed as a tablet-based multi-display environment to foster collaboration between peers by means of several general constraints that were considered during its design. First, the gamification dynamics would need the joint intervention of several patients simultaneously so that no single child could make progress without other peers. Second, the quiz would require the team to explore and discuss the different choices of action to take in 
the pursuit of a goal by means of communication, planning, and negotiation. Finally, it would require the continuous coordination of actions during the course of the activity in real time to reach the predefined goal.

The gameboard is formed by an undetermined number of cells with "items" placed on top, and the leading actor is a robot that can be moved by a set of movement commands (i.e., go forward, stop, turn left or turn right). The items on the cells are keys, walls, and bombs. The keys are the most important items on the board. When one is reached by the robot, the participants will be asked a question and answers will appear on the rest of the cells with keys. The goal is then to lead the robot to the correct answer cell to complete the quiz while avoiding the obstacles represented by the other two types of items: walls that impede the robot and bombs that explode on contact. This approach pursues two objectives: first, to support challenges and replays, two design elements that have been shown to improve engagement, enjoyment, and productive learning experiences [15]; and second, to include emotions and individual versus team responsibility for failed actions as factors that may hinder or empower collaboration, depending on how they are handled by the team.

In order to foster collaboration, Tangibot's main goal, the four movement commands to control the robot are split among the participants so that they are driven to cooperate and coordinate their efforts in order to plan and execute the robot's track on the board. The design rationale behind needing four users to control the robot is because working in small groups has been found effective in collaborative learning, since it "increases each student's opportunity to interact with materials and with other students while learning. Students have more chances to speak in a small group than in a class discussion; and in that setting some students are more comfortable speculating, questioning, and explaining concepts in order to clarify their thinking" (California State Department of Education, 1985). 
With the aim of enabling a more dynamic approach in which physical mobility is encouraged and still provide high levels of workspace awareness, Tangibot was designed to be arranged on the floor, as can be seen in Figure 1.

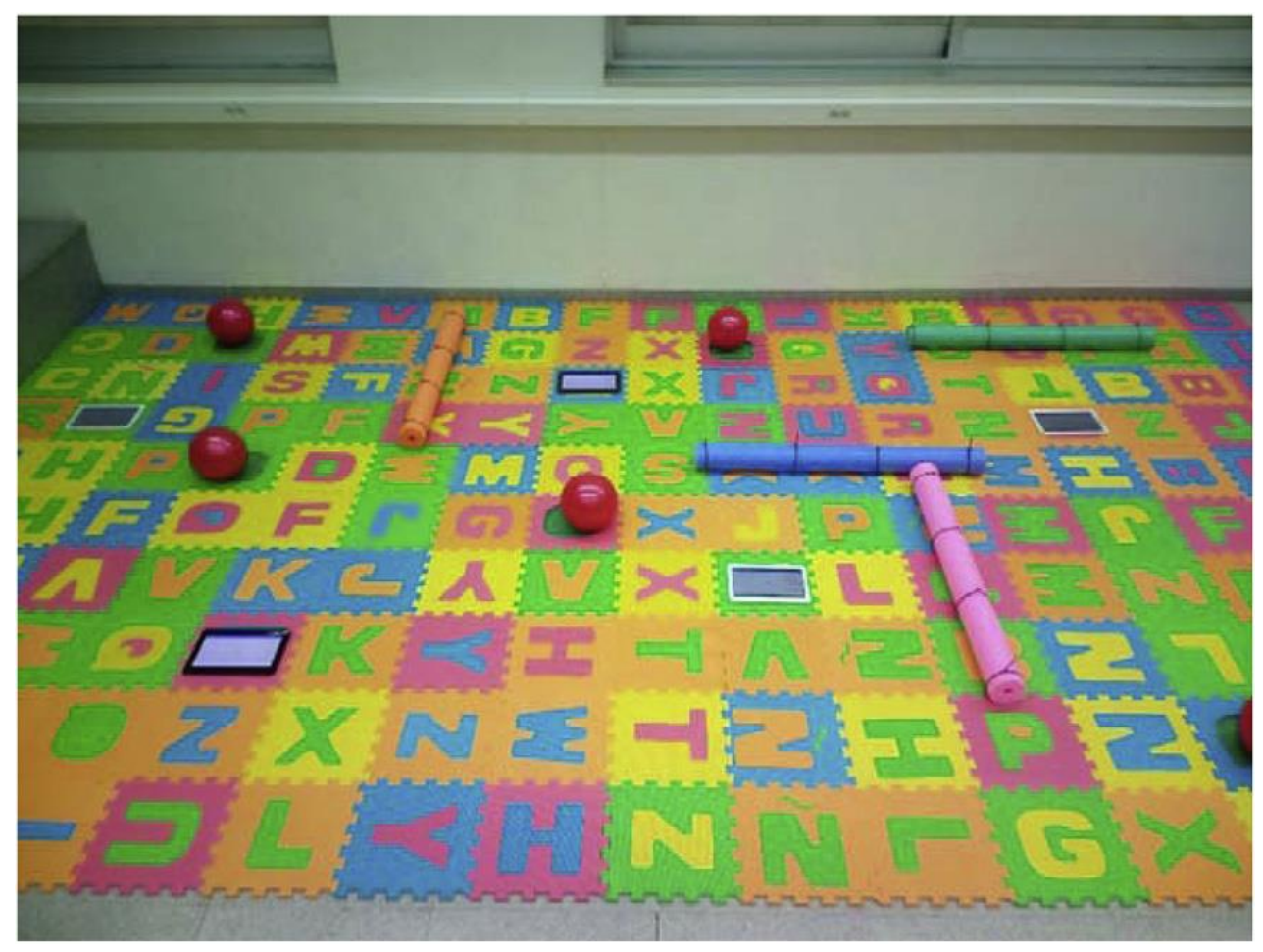

Figure 1: the playing area. The picture was not taken at the hospital, but the location of the elements remains the same.

Each question/answer key cell is displayed on a different tablet to facilitate the dynamic reconfiguration of digital contents as the activity progresses. They are intended to remain fixed during the activity, so that the participants can view their contents at a glance even at a distance. Figure 2 shows how questions are shown to the participants when the robot approaches the corresponding tablet, whereas Figure 3 and Figure 4 show the UI when the players get their answers right or wrong. 


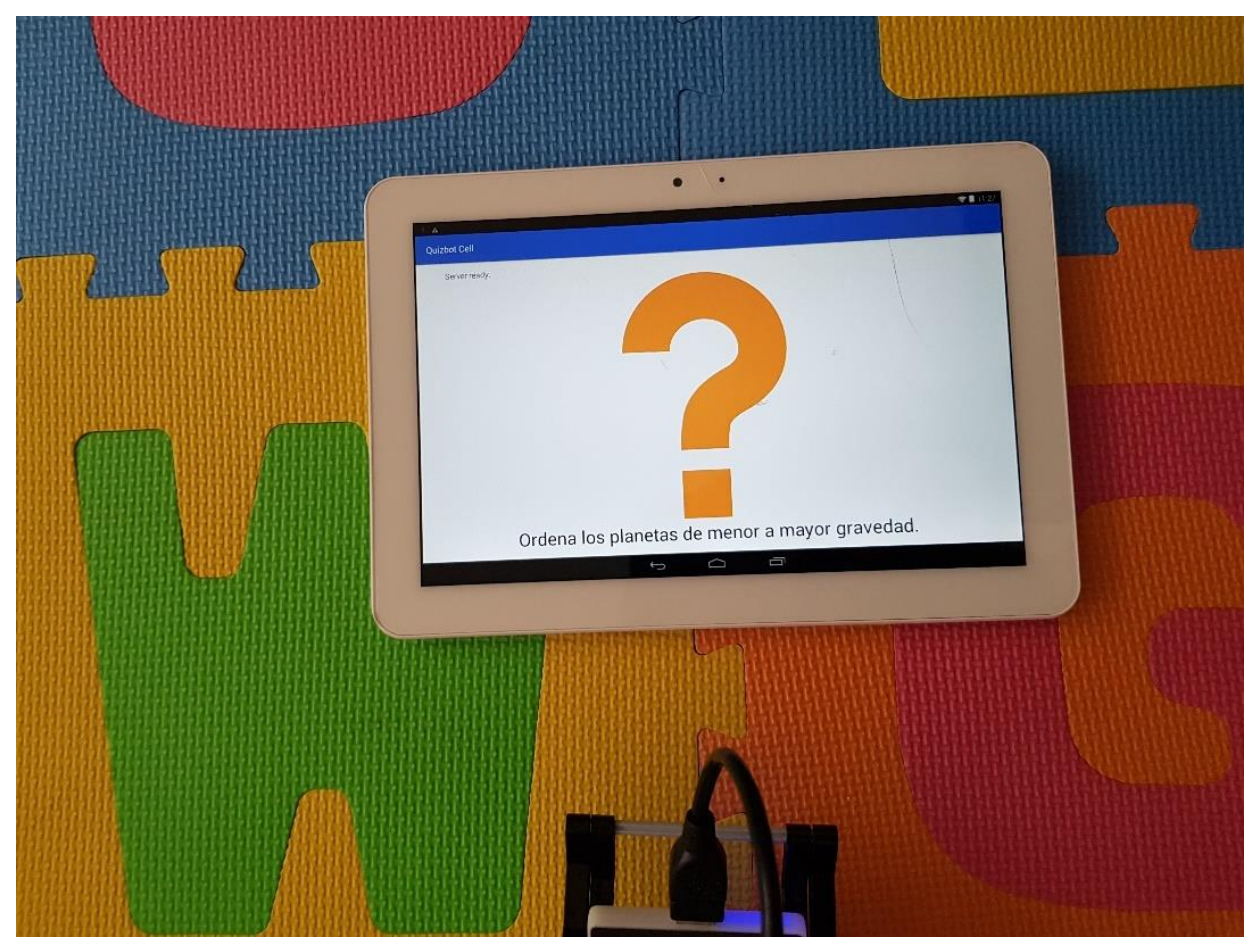

Figure 2: how questions are displayed.

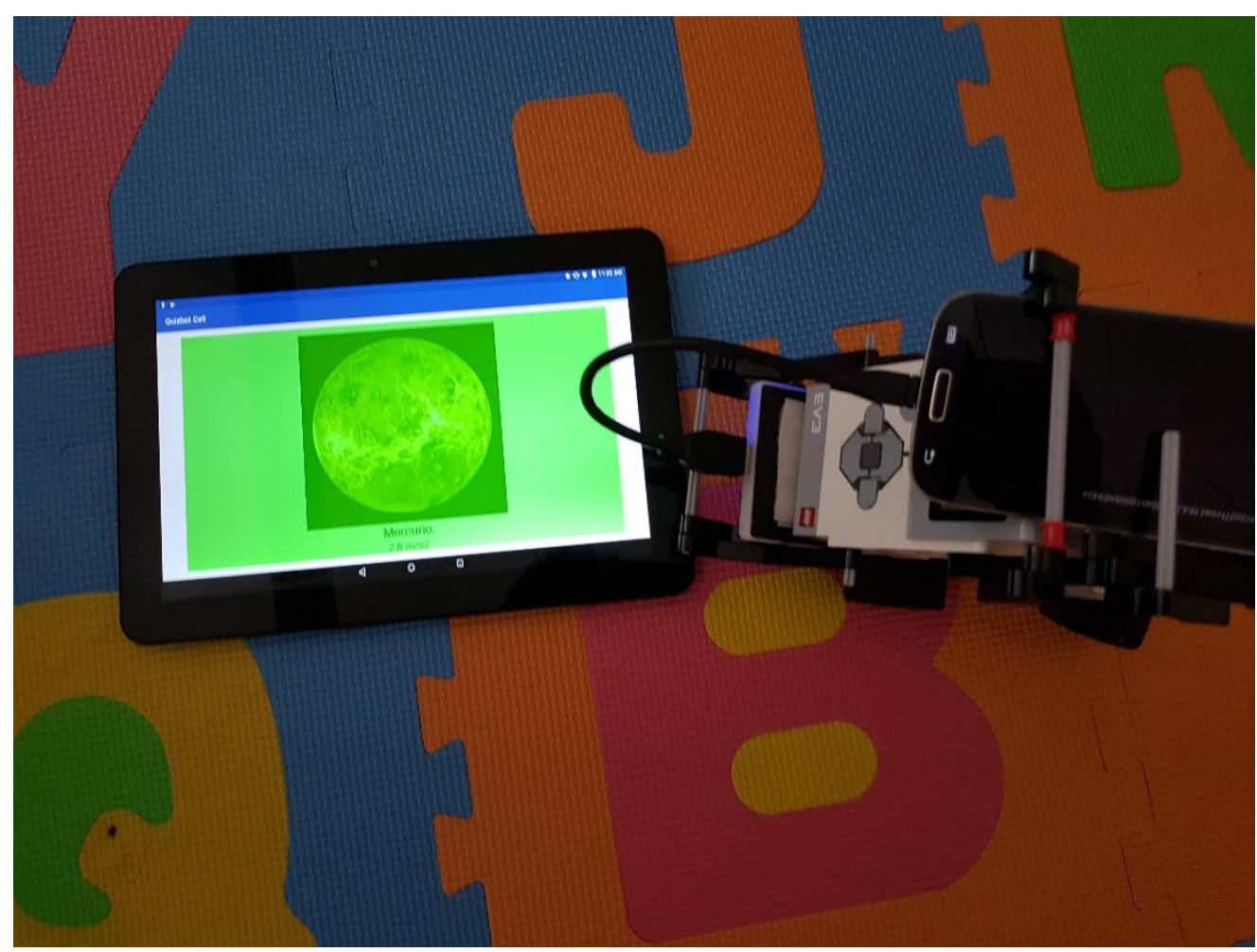

Figure 3: display when the robot approaches the correct answer. 


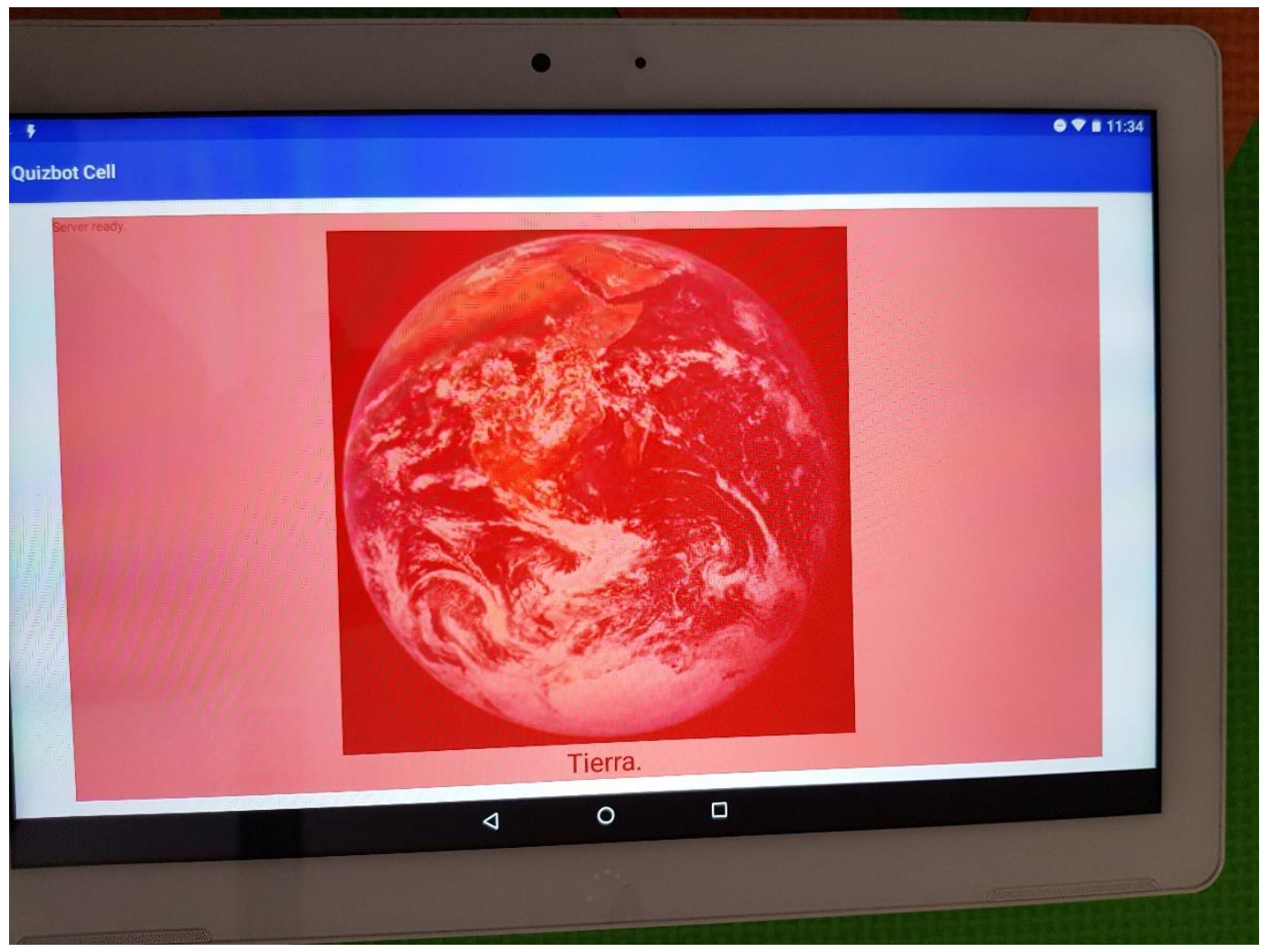

Figure 4: this screen is shown to the players when the robot approaches an incorrect answer.

The board, bombs, walls, and robot are physical artifacts the participants can physically interact with. A physical mobile robot and its paddle-based tangible control interface are used, as it has already been proven usable by children more than 3 years old in tasks that involve following paths [9], [16]. Each movement command is encoded in an RFID tag enclosed in an extensible paddle (see Figure 5), which triggers the corresponding movement of the robot when the users bring the paddle close to its RFID reader. 

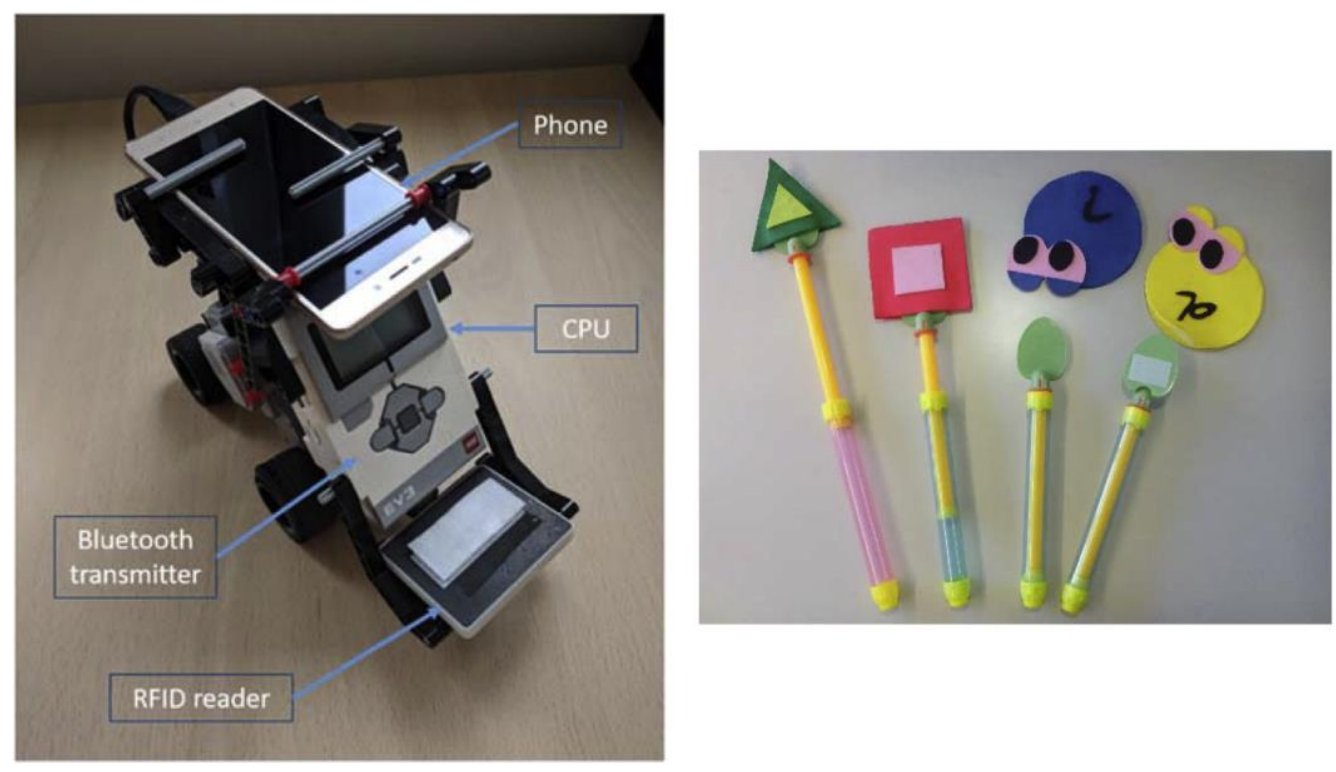

Figure 5: the robot and the control paddles

Since the manipulation of the robot takes place in the real world, the elements that trigger digital events (i.e., bombs and tablets) also have RFID tags attached underneath that are read by Tangibot's RFID reader when it approaches (see Figure 6). The robot's movements are controlled by an application in the robot itself and written in graphical, block-based, Lego Mindstorms programming language. The phone on the robot sends the RFID tags read to a dedicated NodeJS server via an Android app using the Socket.io communication library. The same library is used by the server to send the events that trigger the proper video or audio feedback on the phone or the tablets.
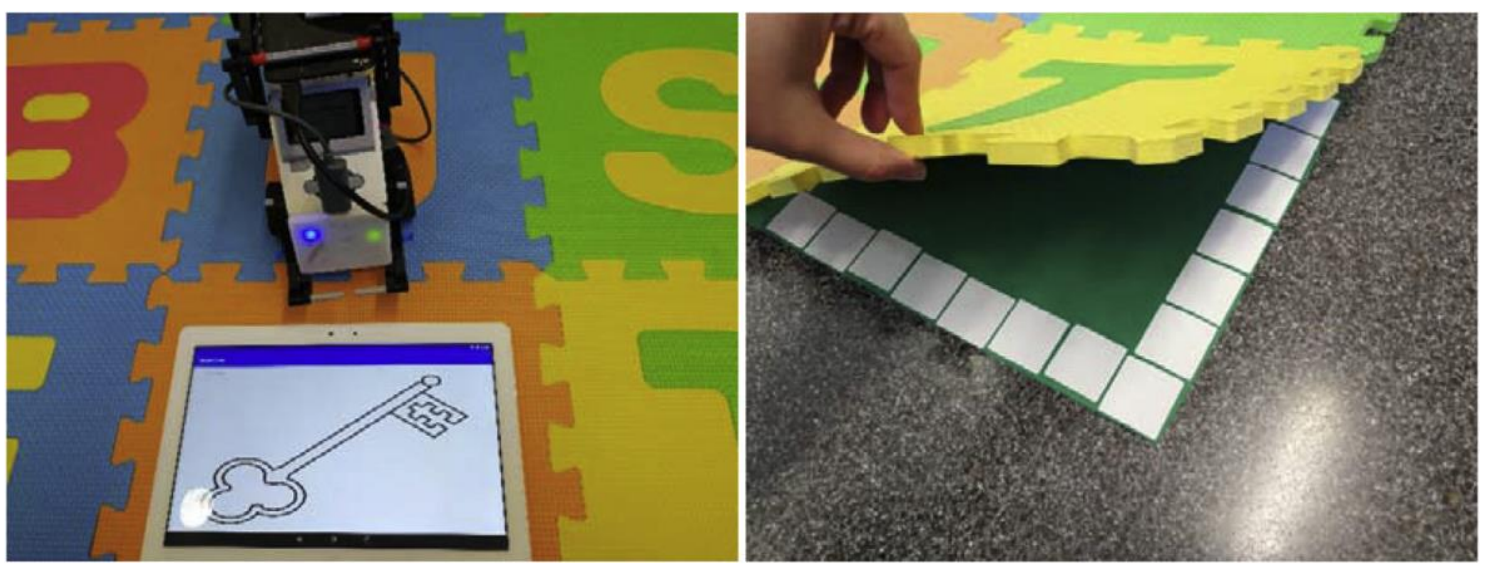

Figure 6: approach of the robot to the tablet and hidden RFID tags 
When the participants get all the answers right, they get a positive feedback on the mobile phone above the robot (which is also used to connect the RFID reader with the server) as shown in Figure 7.

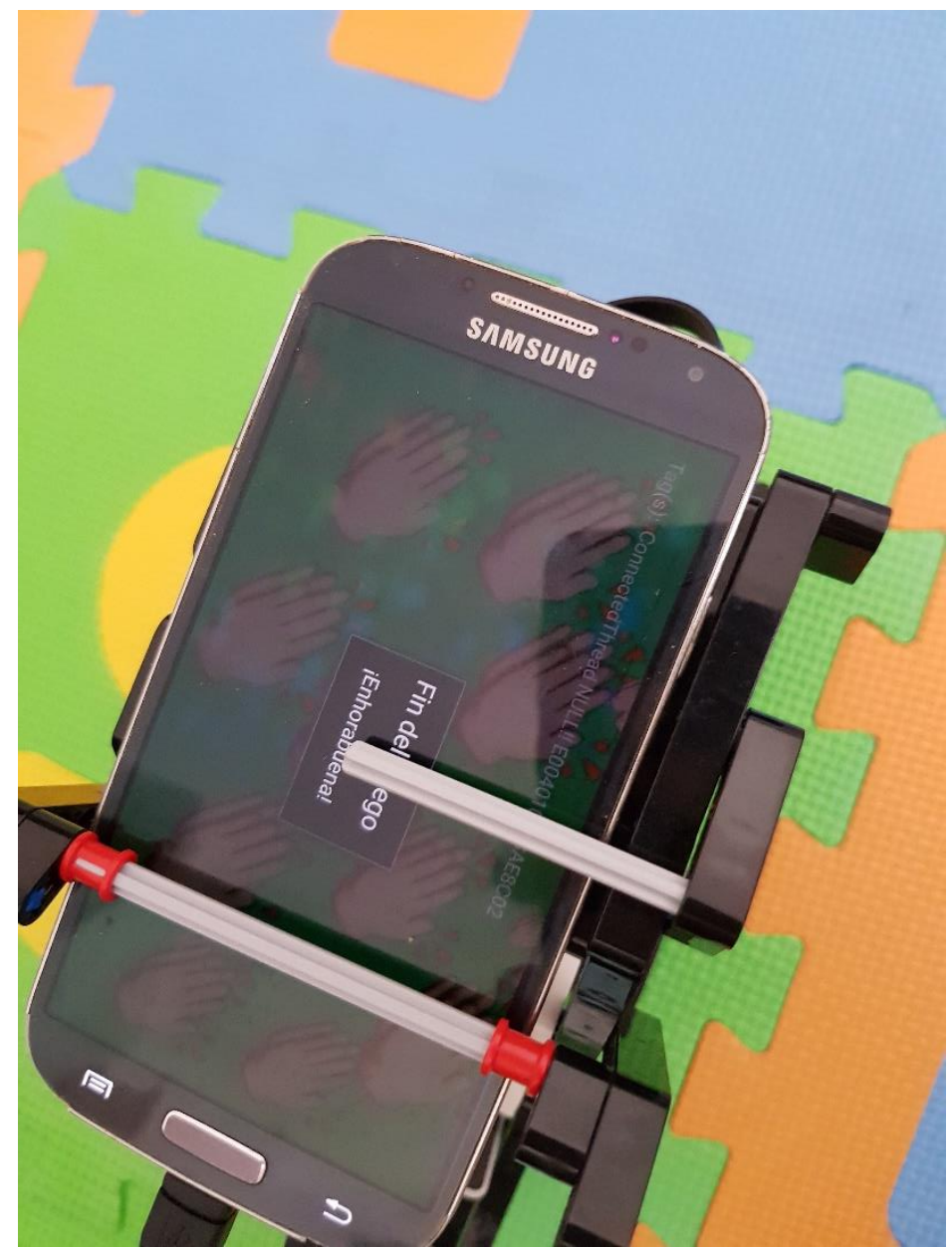

Figure 7: positive feedback when all questions are answered correctly.

\section{Methods}

The main goal of our experimental study was to enhance hospitalized children's collaboration and socialization through educational activities, and to assess the impact of the participation of a teacher in the collaboration and communication and in the psychosocial aspect of the gameplay. By using the Goal Question Metrics [17], it can be defined as follows: analyze the expressions and attitudes of children during the gameplay for the purpose of determining the impact of the game in their short-term psychosocial state and their perception of hospitalization, and the impact of the teacher on communication and coordination from the 
point of view of the interaction and collaboration between the children while using technology in the context of pediatric hospitalization.

Considering all this background, the research questions we formulate in this work are:

- RQ-A: What is the impact of the teacher on communications, joint information processing and interpersonal relationships among the children and with the teacher?

- RQ-B: What is the impact of the teacher on the technical coordination and motivation among the children and with the teacher?

- RQ-C: What is the impact of the teacher on the feelings and perception of the patients about the activity?

- RQ-D: What are the feelings and emotions shown by the participants during the activity?

From these research questions, the following null hypotheses are formulated to be statistically tested:

- $\mathrm{H}_{\mathrm{OA}}$ : The participation of the teacher in the gameplay does not have an impact on the quality of the communications, joint information processing and interpersonal relationship of the participants, in answer to RQ-A.

- $\mathrm{H}_{\mathrm{OB}}$ : The participation of the teacher in the gameplay does not have an impact on the quality of the coordination and motivation of the participants, in answer to RQ-B.

- $\mathrm{H}_{\mathrm{oc}}$ : The participation of the teacher in the gameplay does not have an impact on the psychosocial state of the participants, in answer to RQ-C.

- $H_{O D}$ : The game does not have an impact on the psychosocial aspect of the participants in the short-term, in answer to RQ-D. 


\subsection{Participants}

The children attending the hospital classroom were invited to participate in the game. However, given the nature of the game (which requires some physical activity), those with severe mobility restrictions could not take part.

For both types of session, 20 children with a variety of ailments took part in the experiment, with ages ranging from 4 to 12 , with an average of 8.16 and a standard deviation of 2.93. 13 (65\%) were males and 7 (35\%) were females.

\subsection{Apparatus}

For the experiment, six Android-based tablets were used with a Lego EV3 robot (see Figure 5) fitted with RFID readers that controlled the robot by orders from the palettes, plus an Androidbased mobile phone (which communicated with the robot via Bluetooth) that provided feedback to the players regarding correct answers or exploding bombs and was also connected to the server to receive commands or information.

All the tablets ran a Java application which communicated with the central server by the Socket.IO library. The server was implemented with Javascript and was run as an instance of a NodeJS server.

\subsection{Procedure}

The game was tested in the pediatric classroom of a hospital in Valencia (Spain) in May and June 2018. Each session was played in two parts, in a different order in different sessions: one included a teacher as part of the group, while the other was with children only. This was to test the impact of the teacher on the emotional, social and communicative aspects of the game. Initially, the children were introduced to the robot and given a brief explanation of how it worked. They were then invited to share out the roles and to start playing for 20 minutes or 
until the session was interrupted for any external reason. Sessions of less than 10 minutes were not considered in the results.

\subsection{Evaluation method}

Three main evaluation methods were used to measure the three different aspects covered by the study: psychosocial effect, players' communication and coordination, and user experience.

An ad hoc measurement scale was used to measure the psychosocial effect. This scale analyzed seven dimensions and rated them with a score between 0 and 3 , as detailed in Table 1:

Table 1: analyzed psychosocial dimensions

\begin{tabular}{|c|c|c|}
\hline Dimension & Description & Scoring system \\
\hline Affection & $\begin{array}{l}\text { Facial or corporal } \\
\text { expressions which denote } \\
\text { some emotion }\end{array}$ & $\begin{array}{l}\text { 0: serious expression. Seems } \\
\text { sad, bored or in pain. } \\
\text { 1: no emotion shown by the } \\
\text { participant. } \\
\text { 2: smiles or shows some } \\
\text { enjoyment. } \\
\text { 3: shows enthusiasm, laughs } \\
\text { or is positively surprised. }\end{array}$ \\
\hline Somatic complaints & $\begin{array}{l}\text { Verbal, facial or corporal } \\
\text { expressions which denote } \\
\text { some pain or discomfort. }\end{array}$ & $\begin{array}{l}\text { 0: shows } 2 \text { or more } \\
\text { expressions of pain. } \\
\text { 1: shows } 2 \text { expressions of } \\
\text { pain. } \\
\text { 2: shows } 1 \text { expression of }\end{array}$ \\
\hline
\end{tabular}




\begin{tabular}{|c|c|c|}
\hline & & $\begin{array}{l}\text { pain. } \\
\text { 3: does not show any } \\
\text { expression of pain. }\end{array}$ \\
\hline Physical activity & $\begin{array}{l}\text { Movements performed by } \\
\text { the kid during gameplay, } \\
\text { considering his medical } \\
\text { possibilities. }\end{array}$ & $\begin{array}{l}\text { 0: the child does not move } \\
\text { during the activity. } \\
\text { 1: the child does not move } \\
\text { much during the activity. } \\
\text { 2: the child moves } \\
\text { moderately during the } \\
\text { activity. } \\
\text { 3: the child is very active, } \\
\text { waving his arms, running or } \\
\text { jumping. }\end{array}$ \\
\hline Nervousness & $\begin{array}{l}\text { Repetitive uncontrolled } \\
\text { moves; verbal, facial or } \\
\text { corporal expressions which } \\
\text { denote fear or worries. }\end{array}$ & $\begin{array}{l}\text { 0: shows } 2 \text { or more } \\
\text { expressions or signs of } \\
\text { nervousness. } \\
\text { 1: shows } 2 \text { expressions or } \\
\text { signs of nervousness. } \\
\text { 2: shows } 1 \text { expression or sign } \\
\text { of nervousness. } \\
\text { 3: does not show any sign of } \\
\text { nervousness. }\end{array}$ \\
\hline
\end{tabular}




\begin{tabular}{|c|c|c|}
\hline Social interaction & $\begin{array}{l}\text { How the child interacts with } \\
\text { the other participants. }\end{array}$ & $\begin{array}{l}\text { 0: plays individually. } \\
\text { 1: the child responds to the } \\
\text { direction of a third person. } \\
\text { 2: the child acts as a director } \\
\text { of the activity. } \\
\text { 3: the child collaborates with } \\
\text { the other children on equal } \\
\text { terms. }\end{array}$ \\
\hline Interest & $\begin{array}{l}\text { Pays attention to the tool } \\
\text { and to its different } \\
\text { functionalities. }\end{array}$ & $\begin{array}{l}\text { 0: does not pay attention or } \\
\text { does not want to play. } \\
\text { 1: the child uses the tool but } \\
\text { does not explore its full } \\
\text { functionalities. } \\
\text { passively. } \\
\text { 2: shows some interest and } \\
\text { plays actively, exploring its } \\
\text { functionalities. } \\
\text { 3: gives suggestions to } \\
\text { improve the tool, asks for } \\
\text { more play time or shows } \\
\text { interest in using it again at } \\
\text { another time. }\end{array}$ \\
\hline Satisfaction & Verbal expressions regarding & 0: makes \\
\hline
\end{tabular}




\begin{tabular}{|l|l|l|}
\hline the activity. & $\begin{array}{l}\text { comment regarding the } \\
\text { activity. } \\
1: \text { does not make any } \\
\text { comment. } \\
2: \text { makes one positive } \\
\text { comment regarding the } \\
\text { activity. } \\
3: \text { makes two or more } \\
\text { positive comments about } \\
\text { the activity. }\end{array}$ \\
\hline
\end{tabular}

All these dimensions were evaluated three times in each session: at the beginning, mid-session and at the end, by two independent observers.

The use of this ad-hoc scale was motivated because a lack of validated observational scales was observed for the evaluation of the behavior (physical, emotional and psychosocial) manifested by children aged 0 to 6 years and adults in difficult contexts, such as continuous interaction or a complex clinical state in the hospital's environment.

For this purpose, an initial non-systematic observation was made over one month, focused on hospital life, natural interaction between patient and caregiver, and the psychosocial factors involved. The work of Artilheiro [18] and Montoya-Castilla [19] was also used as an example in developing the observational scale. A reliability study was conducted. This study included 58 patients $(M=7.00$ years; $T D=3.28$ years; $33 \%$ girls $)$ and 22 caregivers $(M=39.00$ years; $T D=$ 5.23 years; $73 \%$ women). The observation was carried out in the Pediatric and Hematooncological Unit of the Hospital Universitari i Politècnic La Fe in Valencia. For the analysis of 
the data, the Kappa interobserver concordance index was calculated. The results showed very good inter-judge concordance for the features Nervousness, Physical Activity and Somatic Complaints ( $\mathrm{K}=0.94 ; 0.87 ; 0.90)$; and good in the features Affection, Interaction and Interest $(\mathrm{K}=0.65 ; 0.75 ; 0.77) ;$ In caregivers the concordance was very good for Nervousness and Emotional Reaction ( $\mathrm{K}=0.90 ; 0.86)$; good for the Interaction and Interest trait $(\mathrm{K}=0.67 ; 0.68)$; and moderate for the Affect trait $(K=0.60)$.

A Smileyometer [20], [21] was used for the user experience. This is a 5-point Likert scale with values represented by smiley faces. This test was conducted twice: before and after the session.

The children's communication and coordination during the gameplay was assessed by the questionnaire designed by Meier et al. [22], with some minor adaptations for children. The questionnaire contains nine items related to five collaboration aspects, which are ranked on a Likert scale of 4 points from -2 (very bad) to +2 (very good). The assessment was performed by two independent observers. The nine items and their group aspects were the following:

- Communication

1. Sustaining mutual understanding

2. Dialogue management

- Joint information processing

3. Information pooling

4. Reaching consensus.

- Coordination

5. Task division

6. Time management 
7. Technical coordination

- Interpersonal relationship

8. Reciprocal interaction

- Motivation

9. Joint task orientation

\section{Results}

To answer the research questions, a series of statistical tests were carried out with the data collected during the evaluation. Regarding the statistical tests performed on the data, t-tests and two-factor ANOVA tests were used, as the Likert scale data in this study represent a discretization of a continuous variable that represents a degree of agreement. These tests are valid and powerful and provide the same protection against false positives as non-parametric tests for this case, as discussed in [23].

First, with the aim of answering RQ-A and RQ-B, the data collected for the communication aspect of the experiment was analyzed using a two-part dependent t-test: first, communication and coordination between children playing alone was compared to that between children (excluding communications with the teacher) when the teacher was present. This data can be seen in Table 2.

Table 2: comparison of communication and coordination between children when the teacher was present and absent.

\begin{tabular}{|l|l|l|l|l|l|l|l|l|}
\hline & Mean & N & Std. & & & & Sig. & (2- \\
& & & & Eeviation & & df & tailed) \\
\hline Sustaining & Without & -1.35 & 20 & .844 & .189 & .309 & 19 & .761 \\
\hline
\end{tabular}




\begin{tabular}{|c|c|c|c|c|c|c|c|c|}
\hline \multirow{2}{*}{$\begin{array}{l}\text { mutual } \\
\text { understanding }\end{array}$} & teacher & & & & & & & \\
\hline & $\begin{array}{l}\text { With } \\
\text { teacher }\end{array}$ & -1.40 & 20 & .852 & .191 & & & \\
\hline \multirow{2}{*}{$\begin{array}{l}\text { Dialogue } \\
\text { management }\end{array}$} & $\begin{array}{l}\text { Without } \\
\text { teacher }\end{array}$ & .65 & 20 & 1.137 & .254 & \multirow{2}{*}{1.143} & \multirow{2}{*}{19} & \multirow{2}{*}{.267} \\
\hline & $\begin{array}{l}\text { With } \\
\text { teacher }\end{array}$ & .35 & 20 & .875 & .196 & & & \\
\hline \multirow{2}{*}{$\begin{array}{l}\text { Information } \\
\text { pooling }\end{array}$} & $\begin{array}{l}\text { Without } \\
\text { teacher }\end{array}$ & -.35 & 20 & 1.387 & .310 & \multirow{2}{*}{.705} & \multirow{2}{*}{19} & \multirow{2}{*}{.490} \\
\hline & $\begin{array}{l}\text { With } \\
\text { teacher }\end{array}$ & -.58 & 20 & 1.055 & .236 & & & \\
\hline \multirow{2}{*}{$\begin{array}{l}\text { Reaching } \\
\text { consensus }\end{array}$} & $\begin{array}{l}\text { Without } \\
\text { teacher }\end{array}$ & .40 & 20 & 1.210 & .270 & \multirow{2}{*}{.391} & \multirow{2}{*}{19} & \multirow{2}{*}{.700} \\
\hline & teacher & .30 & 20 & .657 & .147 & & & \\
\hline \multirow{2}{*}{ Task division } & $\begin{array}{l}\text { Without } \\
\text { teacher }\end{array}$ & .30 & 20 & 1.069 & .239 & \multirow{2}{*}{.674} & \multirow{2}{*}{19} & \multirow{2}{*}{.509} \\
\hline & $\begin{array}{l}\text { With } \\
\text { teacher }\end{array}$ & .13 & 20 & .930 & .208 & & & \\
\hline \multirow{2}{*}{$\begin{array}{l}\text { Time } \\
\text { management }\end{array}$} & $\begin{array}{l}\text { Without } \\
\text { teacher }\end{array}$ & .93 & 20 & 1.029 & .230 & \multirow[t]{2}{*}{.677} & \multirow[t]{2}{*}{19} & \multirow[t]{2}{*}{.507} \\
\hline & With & .65 & 20 & 1.226 & .274 & & & \\
\hline
\end{tabular}




\begin{tabular}{|c|c|c|c|c|c|c|c|c|}
\hline & teacher & & & & & & & \\
\hline \multirow{2}{*}{$\begin{array}{l}\text { Technical } \\
\text { coordination }\end{array}$} & $\begin{array}{l}\text { Without } \\
\text { teacher }\end{array}$ & .65 & 20 & 1.309 & .293 & \multirow[t]{2}{*}{1.220} & \multirow[t]{2}{*}{19} & \multirow[t]{2}{*}{238} \\
\hline & $\begin{array}{l}\text { With } \\
\text { teacher }\end{array}$ & .23 & 20 & 1.141 & .255 & & & \\
\hline \multirow{2}{*}{$\begin{array}{l}\text { Reciprocal } \\
\text { interaction }\end{array}$} & $\begin{array}{l}\text { Without } \\
\text { teacher }\end{array}$ & .80 & 20 & 1.399 & .313 & \multirow{2}{*}{.698} & \multirow{2}{*}{19} & \multirow{2}{*}{.494} \\
\hline & teacher & .60 & 20 & 1.353 & .303 & & & \\
\hline \multirow{2}{*}{$\begin{array}{l}\text { Conjoint task } \\
\text { orientation }\end{array}$} & $\begin{array}{l}\text { Without } \\
\text { teacher }\end{array}$ & .93 & 20 & .693 & 155 & \multirow{2}{*}{.767} & \multirow{2}{*}{19} & \multirow{2}{*}{.453 } \\
\hline & teacher & .78 & 20 & .910 & .204 & & & \\
\hline
\end{tabular}

As these results show, there was no difference in the way children communicated and coordinated with each other when the teacher was either present or absent.

However, the communication and coordination among the children with the teacher and between each other (excluding the teacher) were compared when the teacher was part of the group (Table 3).

Table 3: comparison between the communication between the children among themselves and between them and the teacher

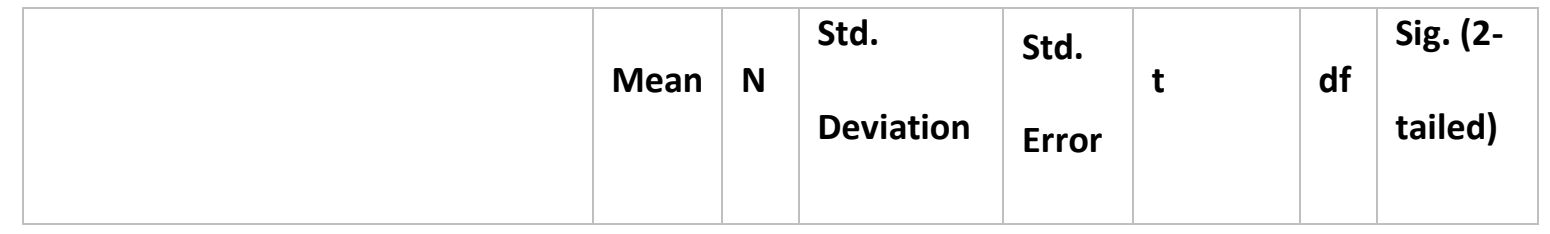




\begin{tabular}{|c|c|c|c|c|c|c|c|c|}
\hline & & & & & Mean & & & \\
\hline \multirow{2}{*}{$\begin{array}{l}\text { Sustaining mutual } \\
\text { understanding }\end{array}$} & $\begin{array}{l}\text { Between } \\
\text { children and } \\
\text { the teacher }\end{array}$ & -.95 & 20 & 1.087 & .243 & \multirow[t]{2}{*}{1.989} & \multirow[t]{2}{*}{19} & \multirow[t]{2}{*}{.061} \\
\hline & $\begin{array}{l}\text { Between the } \\
\text { children }\end{array}$ & -1.40 & 20 & .852 & .191 & & & \\
\hline \multirow{2}{*}{$\begin{array}{l}\text { Dialogue } \\
\text { management }\end{array}$} & $\begin{array}{l}\text { Between } \\
\text { children and } \\
\text { the teacher }\end{array}$ & .98 & 20 & 1.094 & .245 & \multirow[t]{2}{*}{3.387} & \multirow[t]{2}{*}{19} & \multirow[t]{2}{*}{.003} \\
\hline & $\begin{array}{l}\text { Between the } \\
\text { children }\end{array}$ & .35 & 20 & .875 & .196 & & & \\
\hline \multirow{2}{*}{$\begin{array}{l}\text { Information } \\
\text { pooling }\end{array}$} & $\begin{array}{l}\text { Between } \\
\text { children and } \\
\text { the teacher }\end{array}$ & .48 & 20 & .924 & .207 & \multirow[t]{2}{*}{6.658} & \multirow[t]{2}{*}{19} & \multirow[t]{2}{*}{.000} \\
\hline & $\begin{array}{l}\text { Between the } \\
\text { children }\end{array}$ & -.58 & 20 & 1.055 & .236 & & & \\
\hline \multirow{2}{*}{$\begin{array}{l}\text { Reaching } \\
\text { consensus }\end{array}$} & $\begin{array}{l}\text { Between } \\
\text { children and } \\
\text { the teacher }\end{array}$ & .63 & 20 & .483 & .108 & \multirow[t]{2}{*}{2.221} & \multirow[t]{2}{*}{19} & \multirow[t]{2}{*}{.039} \\
\hline & $\begin{array}{l}\text { Between the } \\
\text { children }\end{array}$ & .30 & 20 & .657 & .147 & & & \\
\hline Task division & $\begin{array}{l}\text { Between } \\
\text { children and }\end{array}$ & .08 & 20 & 1.370 & .306 & -.195 & 19 & .847 \\
\hline
\end{tabular}




\begin{tabular}{|c|c|c|c|c|c|c|c|c|}
\hline & the teacher & & & & & & & \\
\hline & $\begin{array}{l}\text { Between the } \\
\text { children }\end{array}$ & .13 & 20 & .930 & .208 & & & \\
\hline \multirow{2}{*}{$\begin{array}{l}\text { Time } \\
\text { management }\end{array}$} & $\begin{array}{l}\text { Between } \\
\text { children and } \\
\text { the teacher }\end{array}$ & .10 & 20 & 1.008 & .225 & \multirow[t]{2}{*}{-4.222} & \multirow[t]{2}{*}{19} & \multirow[t]{2}{*}{.000} \\
\hline & $\begin{array}{l}\text { Between the } \\
\text { children }\end{array}$ & .65 & 20 & 1.226 & .274 & & & \\
\hline \multirow{2}{*}{$\begin{array}{l}\text { Technical } \\
\text { coordination }\end{array}$} & $\begin{array}{l}\text { Between } \\
\text { children and } \\
\text { the teacher }\end{array}$ & -.33 & 20 & 1.004 & .224 & \multirow[t]{2}{*}{-2.010} & \multirow[t]{2}{*}{19} & \multirow[t]{2}{*}{.059} \\
\hline & $\begin{array}{l}\text { Between the } \\
\text { children }\end{array}$ & .23 & 20 & 1.141 & .255 & & & \\
\hline \multirow{2}{*}{$\begin{array}{l}\text { Reciprocal } \\
\text { interaction }\end{array}$} & $\begin{array}{l}\text { Between } \\
\text { children and } \\
\text { the teacher }\end{array}$ & .90 & 20 & .912 & .204 & \multirow[t]{2}{*}{2.042} & \multirow[t]{2}{*}{19} & \multirow[t]{2}{*}{.055} \\
\hline & $\begin{array}{l}\text { Between the } \\
\text { children }\end{array}$ & .60 & 20 & 1.353 & .303 & & & \\
\hline \multirow[t]{2}{*}{$\begin{array}{l}\text { Conjoint task } \\
\text { orientation }\end{array}$} & $\begin{array}{l}\text { Between } \\
\text { children and } \\
\text { the teacher }\end{array}$ & .20 & 20 & .696 & .156 & \multirow[t]{2}{*}{-2.632} & \multirow[t]{2}{*}{19} & \multirow[t]{2}{*}{.016} \\
\hline & Between the & .78 & 20 & .910 & .204 & & & \\
\hline
\end{tabular}




\begin{tabular}{|l|l|l|l|l|l|l|}
\hline children & & & & \\
\hline
\end{tabular}

In this situation there is a significant difference between the way children interact with each other and the way they communicate and coordinate with the teacher. This time, there is an improvement in the communicational aspects of the interaction (dialogue management, information pooling and reaching consensus), which allows us to reject hypothesis $\mathrm{H}_{0 \mathrm{~A}}$. However, there is also reduced performance in terms of technical coordination (time management and individual task orientation), also resulting in the rejection of hypothesis $\mathrm{H}_{0 \mathrm{~B}}$.

To answer RQ-C, a two-factor ANOVA of repeated measures was conducted in which the factors were: the time (the three measures taken) and the presence or absence of the teacher. Given that all the children participated in both types of session, both were considered intrasubject variables. The statistical results can be seen in Table 4 .

Table 4: results of a two-factor ANOVA of repeated measures test regarding participant's psychosocial state during the game.

\begin{tabular}{|l|l|l|l|l|}
\hline & Quadratic Mean & F & df & Sig. \\
\hline time & 1.815 & 4.857 & 1.701 & .018 \\
\hline teacher & .469 & 1.216 & 1 & .284 \\
\hline time*teacher & .065 & .209 & 1.742 & .782 \\
\hline
\end{tabular}

These results show that the only impact on the psychosocial state of the participants during the game was from the time, as detailed in Table 5 and Table 6, which invalidates $H_{O D}$. This means that no impact was observed due to the presence of the teacher during the session, or 
derived from the interaction of both factors, which allowed us to accept hypothesis Hoc. Full details of the teacher's impact can be seen in Table 7.

Table 5: results for each timeframe in sessions without the participation of the teacher.

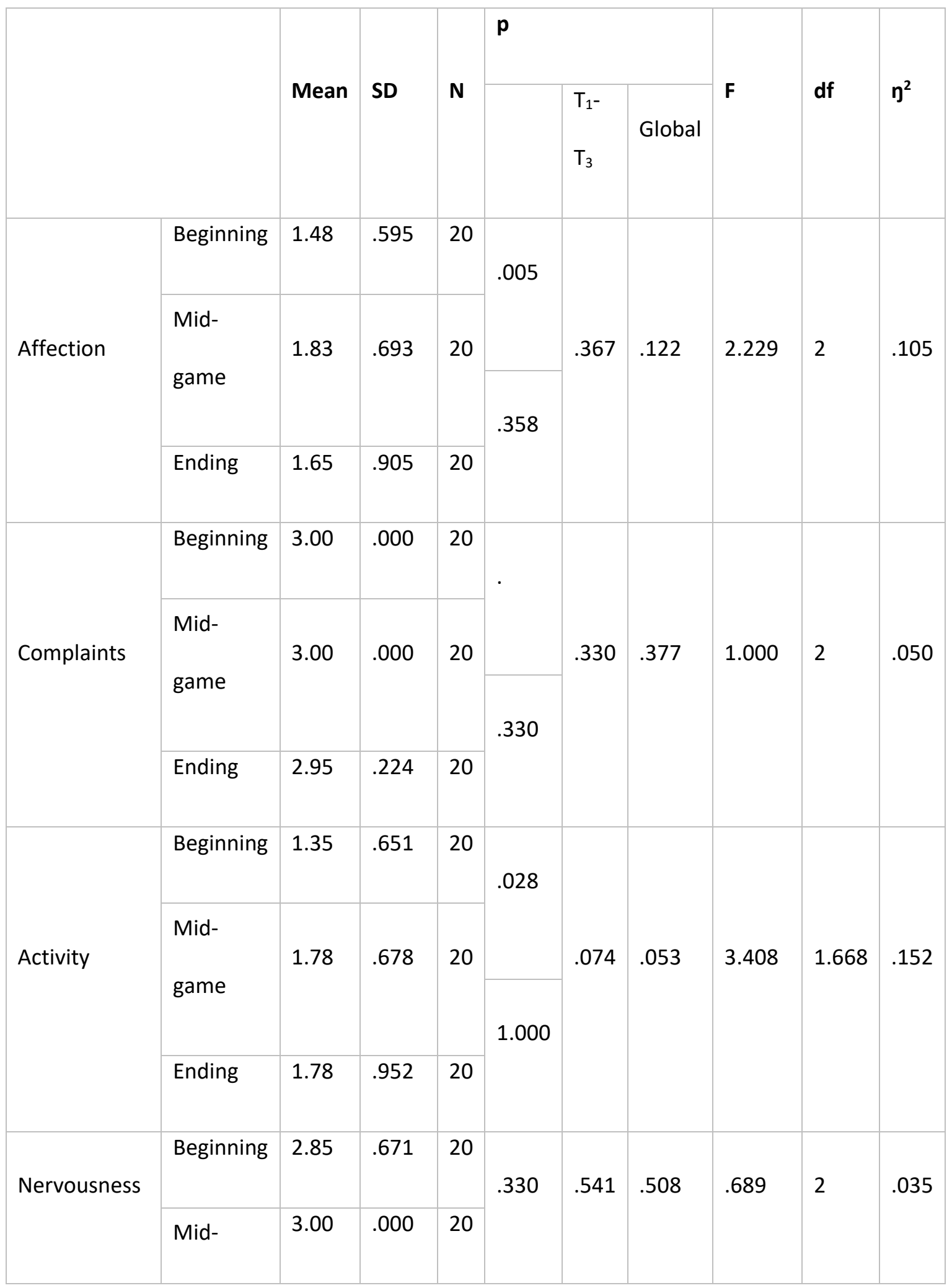




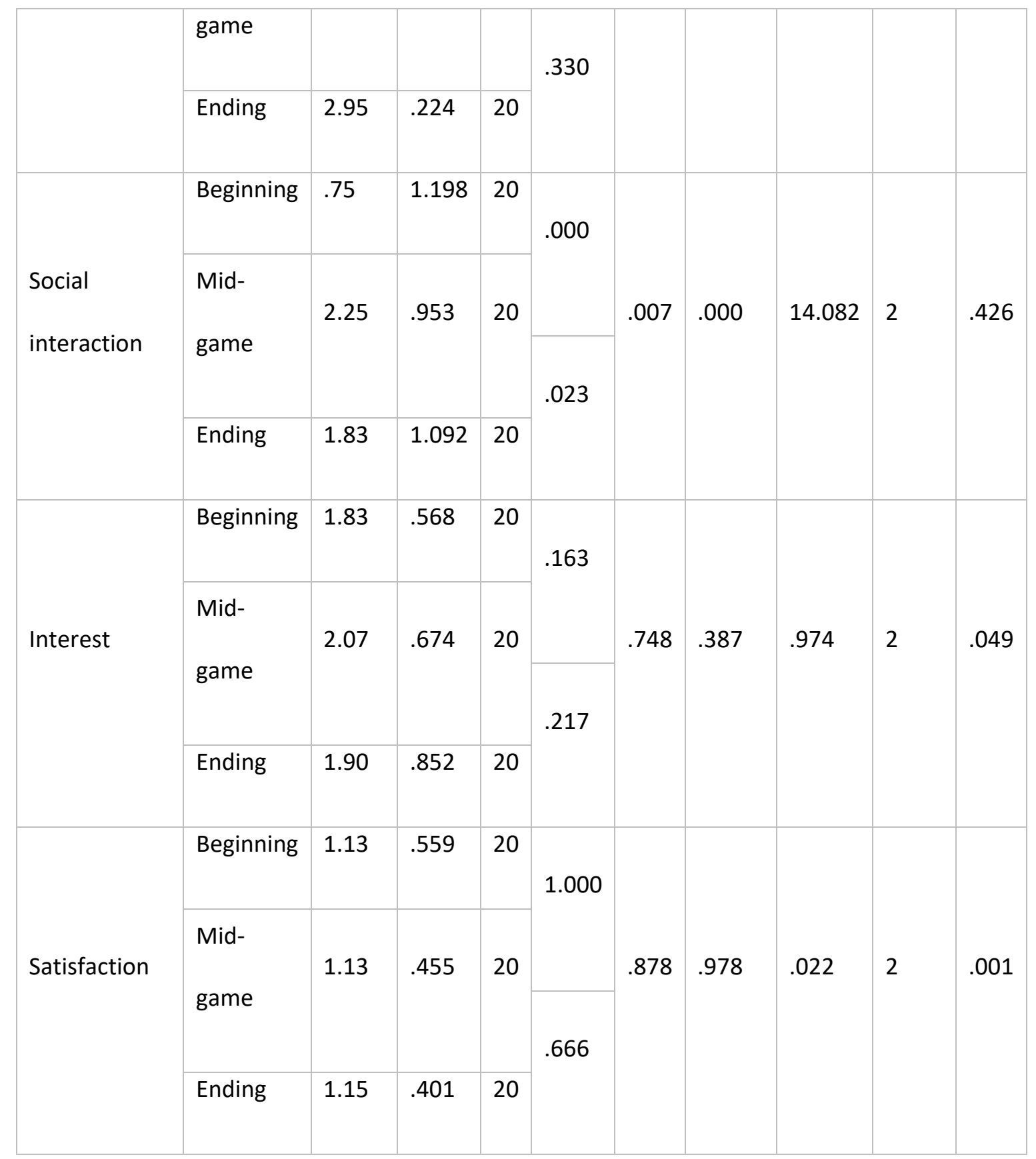

In this case, there are statistically-significant differences for affection (between moments 1 and 2), activity (between moments 1 and 2) and social interaction (moments 1 and 2, 1 and 3 and 2 and 3). This reinforces the rejection of hypothesis $H_{0 D}$, as this data shows a short-term impact on the psychosocial state of the participants. 
Table 6: results for each timeframe in sessions with the participation of the teacher.

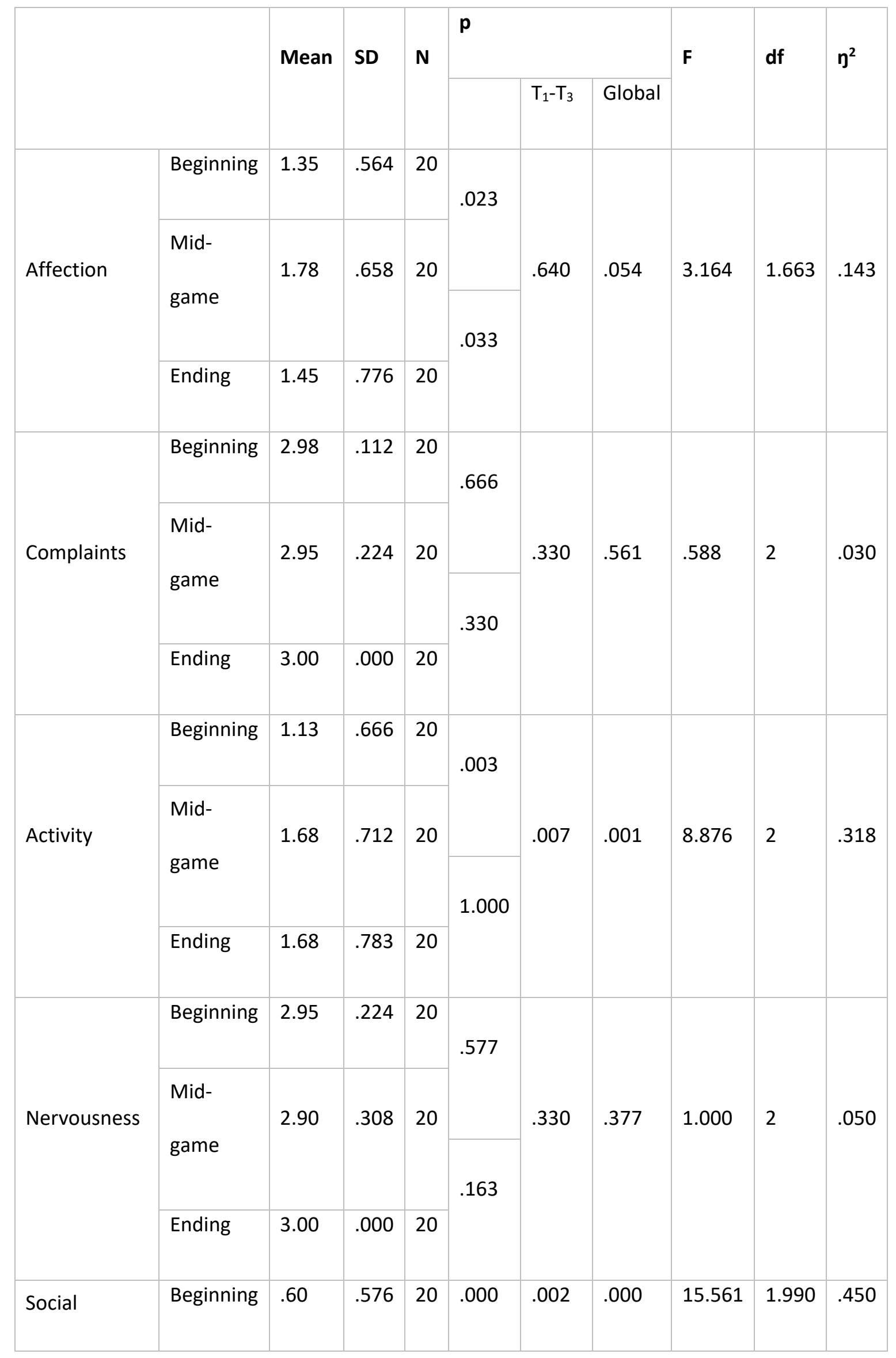




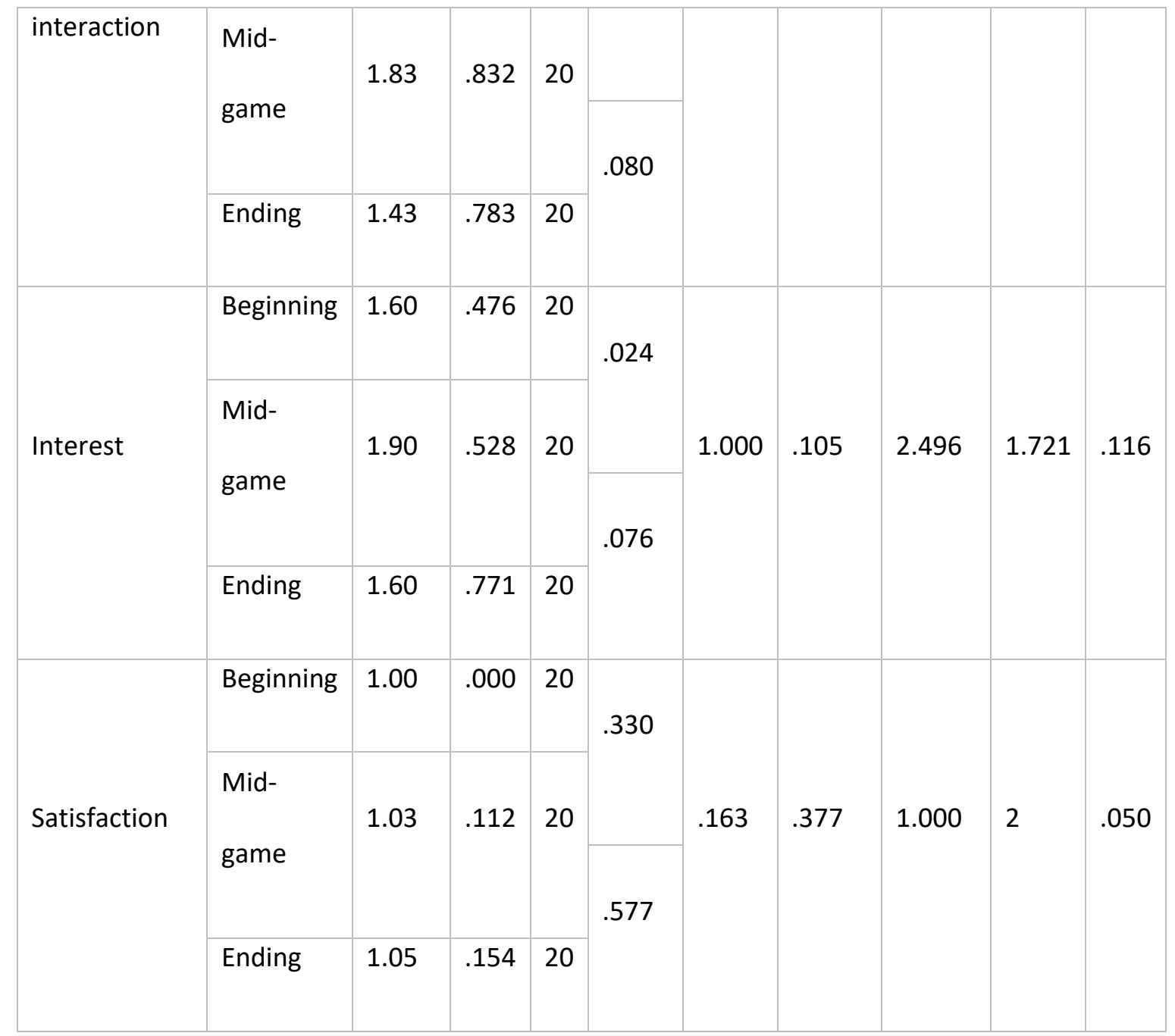

These results show differences for affection (between moments 1 and 2 and moments 2 and 3), physical activity (moments 1 and 2 and 1 and 3), social interaction (moments 1 and 2 and 1 and 3) and interest (moments 1 and 2).

Table 7: results of the ANOVA test to see the impact of the teacher in each of the psychosocial aspects evaluated in each timeframe.

\begin{tabular}{|l|l|l|l|l|l|l|l|l|l|l|}
\hline & & Mean & $\mathbf{N}$ & Std. & F & df & Sig. & $\mathbf{n}^{2}$ \\
\hline Affection & Beginning & Without & Deviation & & & & & & & \\
\hline & & teacher & 1.48 & 20 & .595 & .629 & 1 & .437 & .032 \\
\hline
\end{tabular}




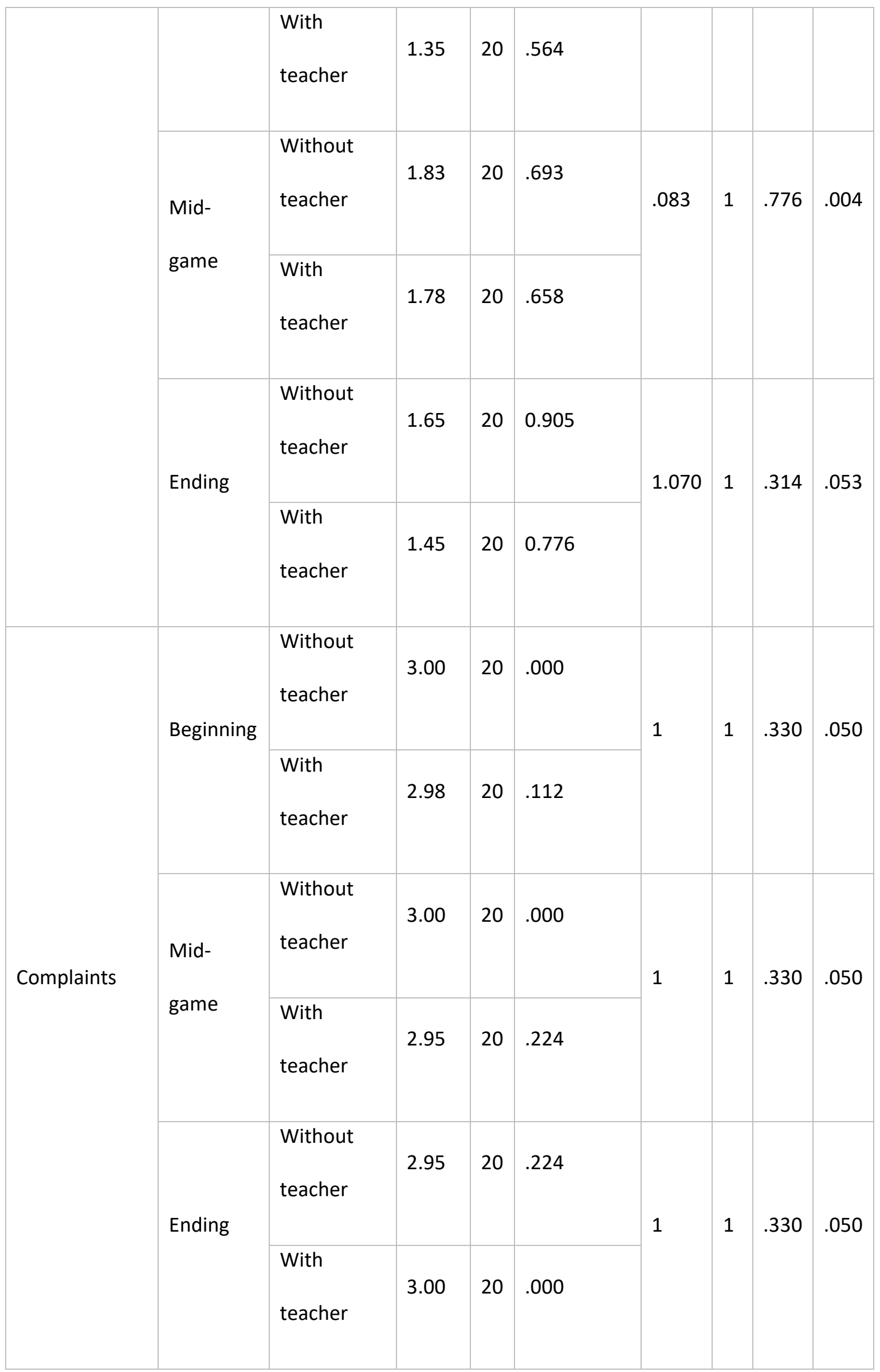




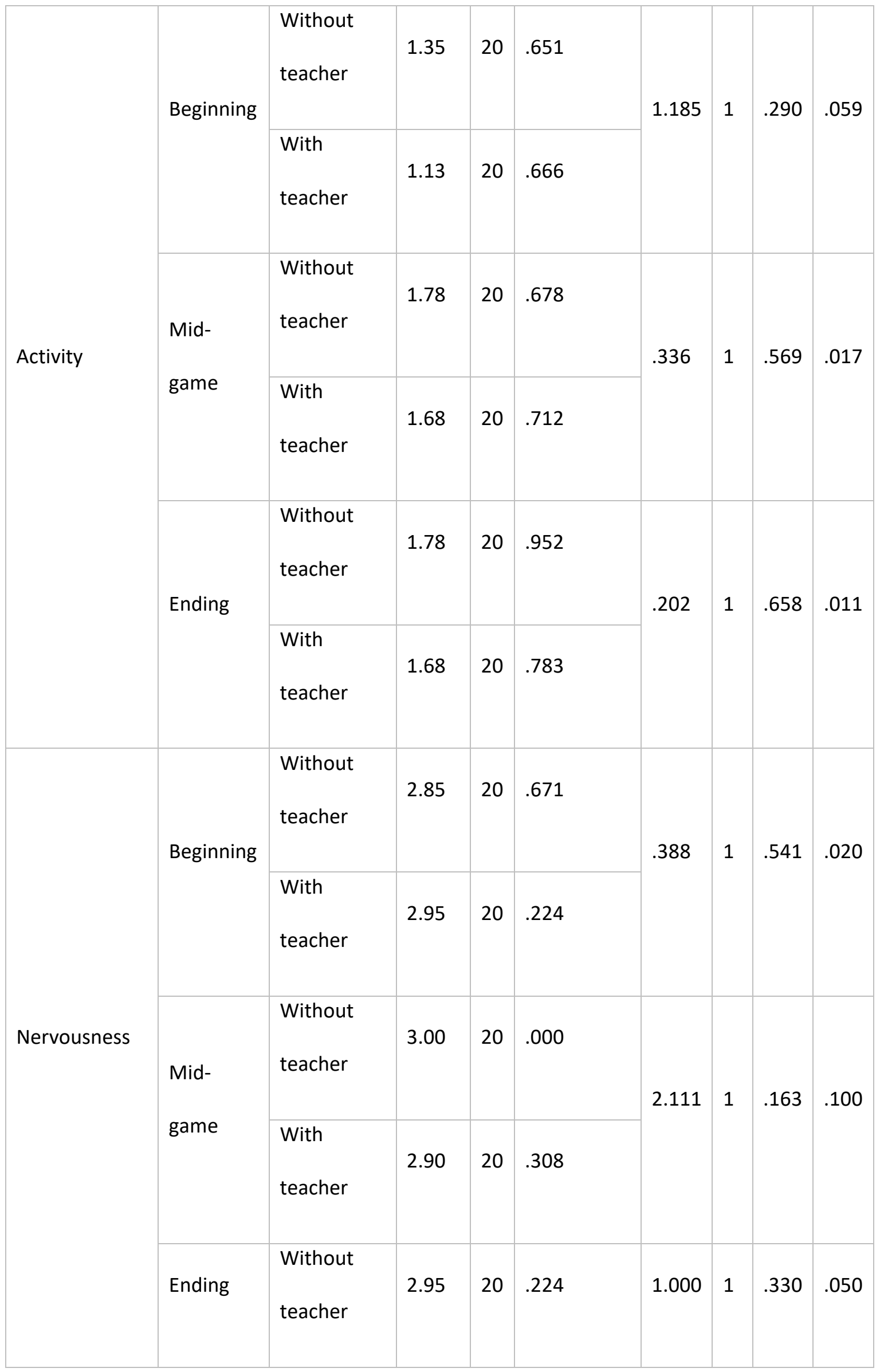




\begin{tabular}{|c|c|c|c|c|c|c|c|c|c|}
\hline & & $\begin{array}{l}\text { With } \\
\text { teacher }\end{array}$ & 3.00 & 20 & .000 & & & & \\
\hline \multirow{3}{*}{$\begin{array}{l}\text { Social } \\
\text { interaction }\end{array}$} & Beginning & $\begin{array}{l}\text { Without } \\
\text { teacher } \\
\text { With } \\
\text { teacher }\end{array}$ & .60 & 20 & .576 & .241 & 1 & .629 & .013 \\
\hline & $\begin{array}{l}\text { Mid- } \\
\text { game }\end{array}$ & $\begin{array}{l}\text { With } \\
\text { teacher }\end{array}$ & 1.83 & 20 & .832 & 2.316 & 1 & .145 & .109 \\
\hline & Ending & $\begin{array}{l}\text { With } \\
\text { teacher }\end{array}$ & 1.43 & 20 & .783 & 1.547 & 1 & .229 & .075 \\
\hline \multirow{2}{*}{ Interest } & Beginning & $\begin{array}{l}\text { With } \\
\text { teacher }\end{array}$ & 1.83 & 20 & .568 & 1.400 & 1 & .251 & .069 \\
\hline & $\begin{array}{l}\text { Mid- } \\
\text { game }\end{array}$ & $\begin{array}{l}\text { With } \\
\text { teacher }\end{array}$ & 1.90 & 20 & .674 & 1.347 & 1 & .260 & .066 \\
\hline
\end{tabular}




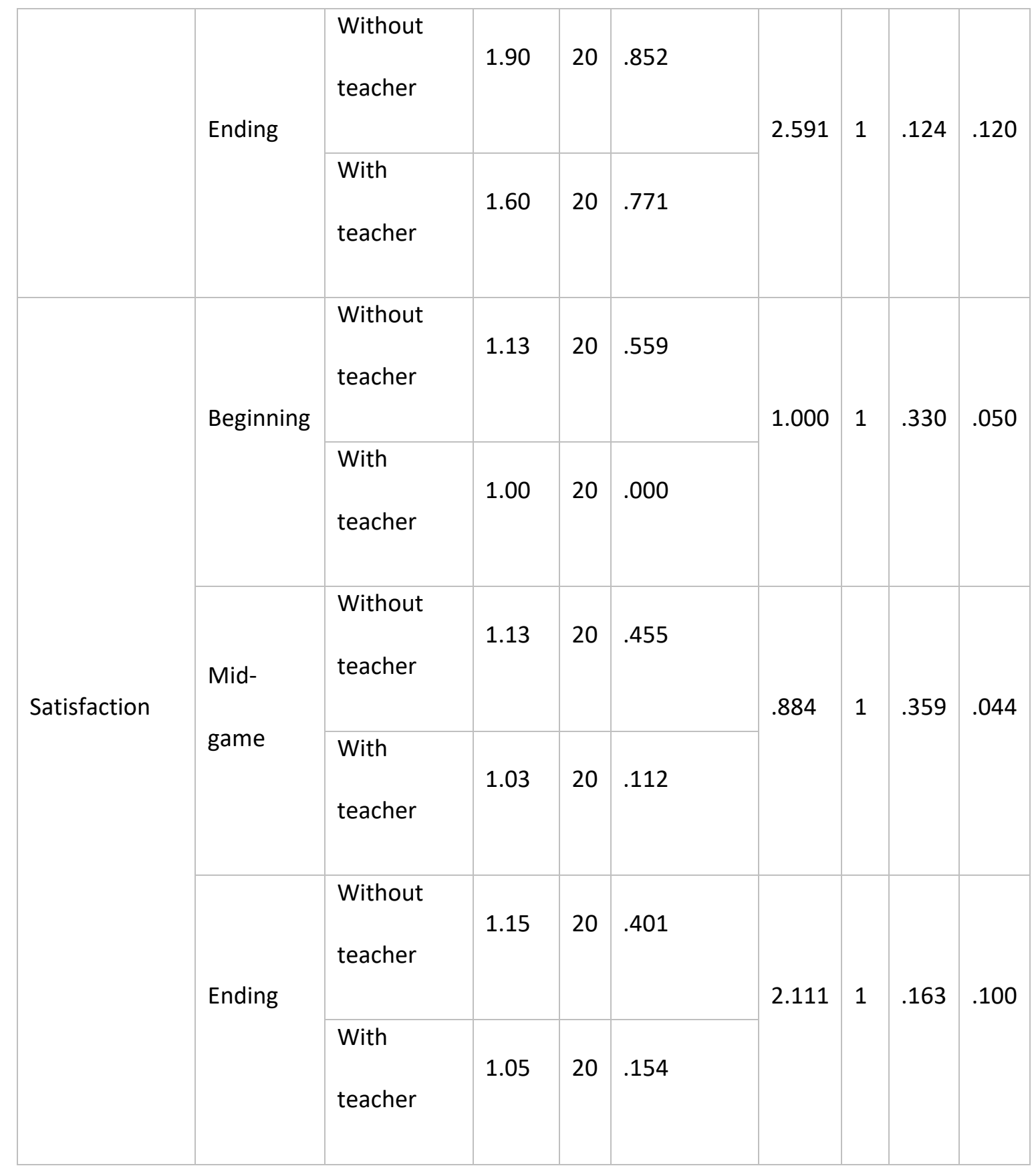

The kappa index for the two observers that participated in the evaluation was computed to test their agreement rate. The result was a kappa index of 0.82 , which translates to "almost perfect", according to Landis and Koch [24].

\subsection{Discussion}

The results obtained show that the teacher's presence had some impact on the children's gameplay, but this was limited to the communication and coordination skills of the 
participants. Playing with their teacher does not change their perception, enjoyment or the number of pain gestures or expressions they displayed. The only factor that produces significant differences in the results of the participants' psychosocial state is the time, which can be translated as the activity itself, as the first measure is taken at the beginning of the session, when they have not yet had time to either like or dislike the game. The effects of the activity on the children can be observed when the second measure was taken in the middle of the playing time.

These results show that the children enjoyed the activity, as there is a significant increase in affection, physical activity and interest (although this was only statistically significant when the teacher was present, the results show that the same tendency applies when the children play alone) and the values for nervousness or complaints remain low. Also, it shows a social interaction closer to full collaboration instead of a hierarchical organization during the game in the case of children playing alone, and a significant improvement in the interaction in both cases (starting from the lack of interaction among peers at the beginning of the game).

However, there is also a tendency to decrease between the middle and end of the game. This is statistically significant in interaction when the teacher was not present and can also be seen in the other aspects even if it cannot be said to be significant at this level of confidence. This can be explained by the overlong duration of the game and the children starting to show signs of boredom. Another possibility is that the difficulty of the questions was either too low or too high and they felt slightly discouraged to carry on with the game. However, it must be noted that, in both types of session, the level of physical activity remains the same at the end and this perceived tendency does not apply to other aspects, which is a positive sign, as the game increases the children's movements beyond the gameplay time.

Considering the actual values obtained instead of the tendency over time, it can be said that the affection results are positive, as the children show signs of fun during most of the activity 
(values between 1 and 2, which are "no emotion displayed" and "some smiles and enjoyment" respectively). Also, the game does not create nervousness, pain or discomfort among the participants, with values for both aspects very close to 3 (no comments or expressions), but it does foster movement, as the results for the physical activity show. This is related to the results obtained for interest: as they are curious about the game, the children explore the playing environment while searching for the tablets with the correct answers, for which they need to move around. However, although they show interest in the game, this does not trigger many spontaneous positive (or negative) comments on it, which explains the results of the satisfaction aspect, which evaluates the number of spontaneous comments made regarding the activity.

In relation to the communication and coordination skills shown by the participants during the game, this time the teacher has a significant impact. The interaction between peers alone or with the teacher is not the same, according to the results. When the children interact with each other, they do so in a different way than when playing with the teacher. In the first case, the results for communication are worse than in the second, but the technical aspects of the evaluation obtain better results. This can be explained because the teacher acts as a moderator during the game without forgetting her instructional role, which makes them partly dependent on her. This would make their technical coordination and time management worse, as they would seek instructions and help from the adult before performing their individual tasks, which thus take longer. On the other hand, this approach improves aspects such as information pooling, possibly because the role of the teacher increases confidence in the answers they receive and so they ask more questions.

For these communication and coordination aspects, the results are not neutral ("neutral" meaning zero on the measurement scale). Most aspects do receive a positive evaluation. However, two communicative aspects are negative in most scenarios: sustaining mutual 
understanding and information pooling. The first can be explained by the evaluation method: the fact of whether the children ensured that the information they had transmitted was understood by the others was taken into account by means of questions like "okay?" or "do you understand it?" or similar, or if they asked for information to be repeated. As this did not happen often during the gameplay, it was evaluated negatively. The children also showed some problems with information pooling, as they did not request enough help and information from their peers. They only did this regularly with the teacher, and this was the reason why the evaluators considered it not to be good enough. This, however, contrasts with the results of the technical aspects, and could have been due to the participants focusing on the tasks they had to perform rather than on interaction.

\section{Conclusions and future works}

A study conducted in a hospital classroom with 20 participants revealed that the teacher has an impact on the children's communication and coordination procedures but has no impact on the psychosocial state of the participants. The teacher's impact was found to be positive about communications. Dialogue management significantly improves when the communication includes the teacher, which means speaking turns are observed more consistently. Information pooling also improves, and the participants ask the teacher more questions. Consensus is also reached more often and more easily, but this does not reflect on the performance, as the time management is evidently worse when the teacher is present, as is also the joint task orientation.

On the other hand, it was found that the teacher does not have an impact on the psychosocial state of the participants during the game, and that it is the game itself which changes their state over time. In the case of affection, which reflects the participants' emotions of joy or boredom, their state improved significantly after a few minutes of play. The same thing occurred for physical activity, interest in the activity and interaction between peers, which 
increased in value in the first part of the game, although physical activity and interaction were reduced towards the end. No changes were found throughout the game in the number of complaints, nervousness or satisfied comments, which remained very low for all these aspects, showing that the game distracted them from their various symptoms.

Based on these results, future work will explore the effects of gamification on the overall hospitalization perception, with special focus on the social opportunities during the hospital stay, to provide ways for the children to meet others during their treatment, to make the experience less painful and reduce their feelings of isolation. Some game strategies should also be evaluated to determine the ones that provide the best opportunities to improve the children's hospital experience.

\section{Threats to validity}

Despite the contributions of this study, there are certain limitations. First, the number of participants in this research is reduced due to the available clinical population which could have an impact on the generalization of the results; and second, a comparison with other forms of measurement of known validity was not included to increase the validity and reliability of the observational scale measures.

\section{Acknowledgements}

This work is funded by the European Development Regional Fund (EDRF-FEDER) and supported by Spanish MINECO with Project TIN2014-60077-R-AR. The work of Jorge Montaner is supported by a national grant from the Spanish Ministry for Education (FPU17/03333). Special thanks to the staff of La Fe Hospital in Valencia who have collaborated in the experiment.

\section{References}

[1] A. Rokach, "Psychological, emotional and physical experiences of hospitalized children," Clin. Case Reports Rev., vol. 2, no. 4, 2016. 
[2] G. L. L. Gomes, M. das G. M. Fernandes, and M. M. L. da Nóbrega, "Ansiedade da hospitalização em crianças: análise conceitual," Rev. Bras. Enferm., vol. 69, no. 5, pp. 940-945, Oct. 2016.

[3] J. E. Rennick and J. Rashotte, "Psychological outcomes in children following pediatric intensive care unit hospitalization: a systematic review of the research," J. Child Heal. Care, vol. 13, no. 2, pp. 128-149, Jun. 2009.

[4] L. Clift, S. Dampier, and S. Timmons, "Adolescents' experiences of emergency admission to children's wards," J. Child Heal. Care, vol. 11, no. 3, pp. 195-207, Sep. 2007.

[5] I. Ø. Olsen, S. Jensen, L. Larsen, and E. E. Sørensen, “Adolescents' Lived Experiences While Hospitalized After Surgery for Ulcerative Colitis," Gastroenterol. Nurs., vol. 39, no. 4, pp. 287-296, 2016.

[6] V. Lambert, J. Coad, P. Hicks, and M. Glacken, "Social spaces for young children in hospital," Child. Care. Health Dev., vol. 40, no. 2, pp. 195-204, Mar. 2014.

[7] A. H. Tahmores, "Role of Play in Social Skills and Intelligence of Children," Procedia Soc. Behav. Sci., vol. 30, pp. 2272-2279, 2011.

[8] R. Rosas et al., "Beyond Nintendo: design and assessment of educational video games for first and second grade students," Comput. Educ., vol. 40, no. 1, pp. 71-94, Jan. 2003.

[9] F. Garcia-Sanjuan, S. Jurdi, J. Jaen, and V. Nacher, "Evaluating a tactile and a tangible multi-tablet gamified quiz system for collaborative learning in primary education," Comput. Educ., 2018.

[10] M. D. Hanus and J. Fox, "Assessing the effects of gamification in the classroom: A longitudinal study on intrinsic motivation, social comparison, satisfaction, effort, and academic performance," Comput. Educ., 2015.

[11] C. Li, Z. Dong, R. H. Untch, and M. Chasteen, "Engaging Computer Science Students through Gamification in an Online Social Network Based Collaborative Learning Environment," Int. J. Inf. Educ. Technol., 2013.

[12] S. Jurdi, J. Montaner, F. Garcia-Sanjuan, J. Jaen, and V. Nacher, "A systematic review of game technologies for pediatric patients," Comput. Biol. Med., vol. 97, 2018.

[13] J. Elicker and C. Fortner-Wood, "Adult-Child Relationships in Early Childhood Programs. Research in Review.," Young Child., 1995.

[14] K. M. Kitzmann and K. M. Howard, "Emotion Socialization by Early Childhood Educators: Conceptual Models from Psychology," Asia-Pacific J. Res. Early Child. Educ., vol. 5, no. 1, pp. 23-44, 2011.

[15] F. F.-H. Nah, Q. Zeng, V. R. Telaprolu, A. P. Ayyappa, and B. Eschenbrenner, "Gamification of Education: A Review of Literature," 2014, pp. 401-409.

[16] V. Nacher, F. Garcia-Sanjuan, and J. Jaen, "Evaluating the Usability of a TangibleMediated Robot for Kindergarten Children Instruction," in 2016 IEEE 16th International Conference on Advanced Learning Technologies (ICALT), 2016, pp. 130-132.

[17] R. van Solingen, V. Basili, G. Caldiera, and H. D. Rombach, "Goal Question Metric (GQM) Approach," in Encyclopedia of Software Engineering, 2002.

[18] A. P. S. Artilheiro, F. de A. Almeida, and J. M. F. Chacon, "Uso do brinquedo terapêutico no preparo de crianças préescolares para quimioterapia ambulatorial," Acta Paul. 
Enferm., vol. 24, no. 5, pp. 611-616, 2011.

[19] I. Montoya Castilla, "Repercusiones psicológicas de la cirugía pediátrica ambulatoria en el paciente y su familia," Universitat de València, 2002.

[20] J. C. Read, "Validating the Fun Toolkit: An instrument for measuring children's opinions of technology," Cogn. Technol. Work, 2008.

[21] J. C. Read and S. MacFarlane, "Using the fun toolkit and other survey methods to gather opinions in child computer interaction," in Proceeding of the 2006 conference on Interaction design and children - IDC'06, 2006.

[22] A. Meier, H. Spada, and N. Rummel, "A rating scheme for assessing the quality of computer-supported collaboration processes," Int. J. Comput. Collab. Learn., 2007.

[23] J. C. F. de Winter and D. Dodou, "Five-point likert items: T test versus Mann-WhitneyWilcoxon," Pract. Assessment, Res. Eval., 2010.

[24] J. R. Landis and G. G. Koch, "The Measurement of Observer Agreement for Categorical Data," Biometrics, vol. 33, no. 1, p. 159, Mar. 1977. 